\title{
PRE-CONTRACTUAL OBLIGATION TO CONFIDENTIALITY OF INFORMATION IN THE PALESTINIAN CIVIL CODE DRAFT AND ITS ROLE IN MAINTAINING ECONOMIC CONTRACTUAL EQUILIBRIUM
}

\author{
${ }^{1}$ Osama Ismail Mohammad Amayreh, \\ ${ }^{2}$ Izura Masdina Mohamad Zakri, \\ ${ }^{3}$ Pardis Moslemzadeh Tehrani \& ${ }^{4}$ Yousef Mohammad Shandi \\ ${ }^{1,2 \& 3}$ Faculty of Law, University of Malaya, Kuala Lumpur, Malaysia \\ ${ }^{4}$ Faculty of Law, Arab American University, Palestine \\ ${ }^{1}$ Corresponding author:adv-osama@outlook.com
}

Received: 19/6/2019 Revised: 21/10/2019 Accepted: 17/11/2019 Published: 24/12/2019

\begin{abstract}
It is inconceivable that a person can be legally obliged to provide influential information to another party in order to contract freely and in an enlightened manner without requiring the latter to maintain the confidentiality of the exchanged information between the parties. In this context, Article 2.1.16 of the UNIDROIT principles of International Commercial Contracts and Article 11122 of the French Decree N 131-2016, etc. tend to apply the obligation to confidentiality of information at the pre-contracting phase as one of the most substantial principles governing this phase. However, the Palestinian legislature, having ignored enacting legal provisions obliging parties to maintain confidentiality of information in the pre-contracting phase, caused legislative deficiencies in the legislative remedies of the subject of confidentiality of information in the pre-contracting phase. As such, as a prime objective, this paper seeks to suggest orientations for the formulation of provisions for the obligation to maintain confidentiality of information in the Palestinian Civil Code Draft. Thus, an analytical comparative approach is used by way of the French civil code, and alluding briefly to German and English law, so as to illustrate the Palestinian legislative deficiencies and the urgent need to legislate a legal article obligating the negotiating parties to maintain confidentiality
\end{abstract}


of information, in order to contribute to the stability of civil and commercial transactions. In this regard, contractual equilibrium entails that the obligation to maintain confidentiality of information has its own independent essence derived from all theories that the jurisprudence adopted has a legal basis for this obligation.

Keywords: Obligation to Confidentiality of Information, Economic Contractual Equilibrium, Palestinian Civil Code Draft, PreContracting Phase, Secrecy of Information.

\section{INTRODUCTION}

Recent industrial and technological developments have resulted in new types of contracts, involving important technical or technological secrecy issues, such as: contracts of technology transfer, ${ }^{4}$ construction and engineering contracts, ${ }^{5}$ technical assistance contracts, ${ }^{6}$ computer software manufacturing contracts, and turn-key contracts. ${ }^{7}$ Thereby, the conclusion of such contracts requires long and arduous negotiations, through which many

4 The contracts of technology transfer are defined as: "a process by which a technology, expertise, knowhow or facilities developed by one individual, enterprise or organization is transferred to another individual, enterprise or organization. Effective technology transfer results in commercialization of a new product or service or in the improvement of an existing product or process". See Tessema, Y. (2016). The Legal Framework for the Transfer of Technology in Ethiopia. Journal of Law, Policy and Globalization, 55, 149. Alkhamees, A. (2011). International Transfer Technology Agreements: New Age of Negotiation. Asian Business Lawyer, 8, 147-150.

5 Such as the Joint Contracts Tribunal, Infrastructure Conditions of Contract and FIDIC Contracts. See Thomas, D. (2012). Standard form Construction and Engineering Contracts: Current and Recent Developments. Construction Law International, 7(2), 3334. For the definition of the construction and engineering contracts, see Al-Saadoon, O. (2010). Federal Iraqi Law Applicable to Construction Contracts. Arab Law Quarterly, 24(1), 107.

6 It can be defined in a simple way as: "an agreement according to which the supplier is obliged to train the employees of the recipient of the service to operate the equipment and machines used in the production process, and to repair, maintain or train them to manage the project by technical means. This is done by sending a number of employees of the recipient of the service to the supplier's facility". See Mansour, H. M. (2009). International Contracts. Alexandria, Egypt: Dar Al-Jamieat Al-Jadidah. 15. Valentino, D. (2016). Software Assistance and Maintenance Contracts. European Business Law Review, 27(4), 535-553.

7 A turn-key contract can be defined as: "an agreement whereby a party undertakes to set up a manufactory and hands it over ready for operation and production". See Woss, H. (2008). The ICC Model Turnkey Contract for Major Projects. Construction Law International, 3(2), 7. 
secrets are revealed, whether they are related to some technical or technological matters or even personal secrets related to financial status or the extent of dealing transactions. ${ }^{8}$ In addition, in some cases, these secrets may relate to the negotiation process itself, since negotiations must be conducted in strict secrecy, in order to keep them away from any external influences that may hinder their normal functioning and; thus, cause their failure.

Therefore, if the confidential information itself is the subject of the contract to be concluded, as in technology transfer contracts, the party who is requesting this technology will always seek to obtain such information. This is so in order to assess the appropriateness of such information to his project, purpose of contracting, and the amount of damage that it may cause as a result of its use, especially to the environment. Besides this, the technology importer aims to balance the price he pays for this technology with its future benefits and profits. In contrast, the possessor of the technical or technological knowledge is always keen during the negotiation phase that the recipient of confidential information should not disclose this information to others or use it for his personal benefit without prior permission. ${ }^{9}$

Accordingly, an obligation arises upon the recipient of confidential information to maintain such secret information, whether explicitly stated in the contract of negotiation or in an independent agreement or not. Hence, in order to take into account the various aspects of this obligation, we are required to study the concept of the obligation to confidentiality of information and the position of the legal legislations and conventions in terms of imposing it as an obligation, and determining its role in ensuring contractual equilibrium between the parties in the pre-contracting phase and determining the scope of this obligation and the guarantees of its implementation.

See Malami, S., \& Yusoff, Z. M. (2017). Legal Regime for the Protection of Banking Consumers in Nigeria: An Overview. UUM Journal of Legal Studies, 8, 106. Santoso, E. (2012). Consumer Protection for Online Banking Scams via e-mail in Malaysia. UUM Journal of Legal Studies, 3, 11.

9 Horton, W. G.; Mathai, S. (2005). Confidentiality in Canadian Civil Litigation. Advocates' Quarterly, 29(4), 382-383. Krishnan, L. (2013). Conceptualising a Fiduciary Duty on Auditors. UUM Journal of Legal Studies, 4, 59. 


\section{DEFINITION OF THE OBLIGATION TO CONFIDENTIALITY OF INFORMATION}

Part of the legal jurisprudence clarifies the obligation to confidentiality of information as: "an obligation which obliges the negotiator to remain silent, in respect of all that is known to him, revealed during the negotiations process, or through what they exchange between each other in the negotiations, or through what happens between them during the discussions, or by coincidence, or through the research and studies which were required in order to conclude the contract". ${ }^{10}$

However, another part of the legal jurisprudence clarifies the obligation to confidentiality of information as: "a piece of information, which has a personal or objective nature that requires the legally recognized benefits of its owner, as the scope of its knowledge remains limited". ${ }^{11}$ Consequently, others define it as: "information, or formulas, models, programs, methods, techniques, mechanisms or means which have an independent economic value". ${ }^{12}$ Moreover, in this regard, the French Supreme Court has defined the

10 See Saleh, A. A. (2011). Negotiations in International Commercial Contracts. Algeria, Algeria: Dar Houma. 481. Reuben, R. C. (2018). Rethinking the Law of Legal Negotiation: Confidentiality Under Federal Rule of Evidence 408 and Related State Laws. Boston College Law Review, 59(2), 531-533. Dobrila, M. M. (2015). Unification of Criteria for the Assessment of Good Faith in Negotiating Contracts: From National to International through the Intercession of the European Experience. AGORA International Journal of Juridical Sciences, 2015(2), 3. Marsden, G. J.; Siedel, G. J. (2017). The Duty to Negotiate in Good Faith: Are BATNA Strategies Legal. Berkeley Business Law Journal, 14, 134. Loncle, J.; Trochon, J. (1997). La Phase de Pourparlers dans les Contrats Internationaux. International Business Law Journal, 1997(1), 3.

11 See Bambauer, D. E. (2016). Secrecy is Dead Long Live Trade Secrets. Denver Law Review, 93(4), 835-837.

12 This clarification is similar to the American definition of trade secrets, where Article 4 of the USA Uniform Trade Secrets Act defines it as: "trade secret means information, including a formula, pattern, compilation, program, device, method, technique, or process, that: 1- derives independent economic value, actual or potential, from not being generally known to, and not being readily ascertainable by proper means by other persons who can obtain economic value from its disclosure or use, and 2-is the subject of efforts that are reasonable under the circumstances to maintain its secrecy". See Gratzinger, P. E. (2015). After O2 Micro: The Court's Evolving Duty to Map Worlds to Things. Santa Clara High Technology Law Journal 32(2), 145. Nashkova, S. (2016). Overview of Contractual Obligations of the Know-How Licensor under the Macedonian Law of Obligations. Collection of Papers, Faculty of Law, Nis 72, 365. Foley, T. W. (2010). Keeping Company's Confidences Secret: Trade Secret Enforcement under Iowa's Uniform Trade Secrets Act. Drake Law Review 59(1), 6. Frankel, M. J. (2012). Secret Sabermetrics: Trade Secret Protection in the Baseball Analytics Field. Albany Government Law Review 5(1), 252. 
confidentiality of information as: "any means of manufacture, formula or any information of economic value, or a process used in business that gives its owner a competitive advantage over those who do not know". ${ }^{13}$

However, it is evident from the above definitions that the obligation to confidentiality of information in the pre-contracting phase concerns the situation of refraining from disclosing or using information that reached the recipient's knowledge. ${ }^{14}$ This is so whether such information is commercial, financial, administrative or technical, and belongs to a particular project or person(s) using it for business, which also has a current or potential economic value, and is difficult for others to obtain with the reasonable efforts by its owners to maintain its confidentiality. ${ }^{15}$

Another obvious thing is that the obligation to confidentiality of information in the pre-contracting phase has two patterns: the first one concerning the confidentiality of the negotiations themselves, in terms of their progress and terms of the contract, the stages of the advancements of the negotiations, the issues agreed upon, and other matters in which the debate is still ongoing. The second pattern, however, relates to the confidentiality of information provided by the negotiating parties, which pertains to the subject of the contract, such as the information provided by the technology supplier to the importer in order to inform him of its value and usage for the purpose that the importer wishes to achieve without becoming a victim of lesion or deception. ${ }^{16}$

Nevertheless, the question of the identification of information deemed confidential has raised considerable legal controversy. In light of this, some jurists think that all information exchanged during the

13 See Mohammedine, W. J. (2004). The Legal Frame of Technology Transfer. Alexandria, Egypt: Dar Al-Jamieat Al-Jadidah. 34. Abdul Ghani, M. (1998). Legal Frame for the Transfer of Technology in Public International Law. Cairo, Egypt: Dar Alnahdah Alearabiah. 66.

14 For example, if the negotiation process requires the acquisition of secret means, in order to facilitate negotiations such as maps and designs, the recipient is obliged to refrain from using them without the consent of the other party, but also to return it in the event of negotiation failure.

15 See Alsagher, A. H. (2005). Protect Undisclosed Information and the Challenges Facing Pharmaceutical Industries in Developing Countries. Alexandria, Egypt: Dar Al-Fikr Aljamiei. 81.

16 What makes the matter of disclosing confidential information more serious is that the negotiator has the right to resort to experts and specialists to examine and evaluate the contract subject, and here these experts or specialists have the ability to detect this confidential information more than the other, since they have jurisdiction in the subject of the contract negotiated. 
negotiation phase is confidential regardless of its nature. ${ }^{17}$ Others, nonetheless, highlight that any information that is considered confidential should be identified precisely. This matter is determined by referring to the agreement between the parties concerning the information that they share. Or else, the judge shall determine the confidential nature of the information by exercising his discretion, using the orgalime guide to conclude the technology transfer contracts as an example, which includes several model formulas for agreeing on the confidential nature of the information exchanged between the parties during the negotiation phase. ${ }^{18}$

Based on what we (the researchers) mentioned, the following definition for the obligation to confidentiality of information in the pre-contracting phase can be derived as: an impact on the negotiating parties, whereby a negotiating party shall conceal and not use information obtained by the other negotiator with regard to the negotiated contract, whose disclosure of information would cause him harm.

\section{THE FUNCTION OF THE OBLIGATION TO MAINTAIN CONFIDENTIALITY OF INFORMATION IN ACHIEVING CONTRACTUAL EQUILIBRIUM AT THE PRE-CONTRACTING PHASE}

The modern era has gone through many enormous economic and technological developments, which have greatly affected the structure of the contract's theory, as many considerable contracts

\footnotetext{
See Saleh, supra note 6 at 485. Sharfuddin, A. (2008). Principles of Legal Drafting of Contracts. Cairo, Egypt: Dar Alnahdah Alearabiah. 74.

18 In view of the legislative insufficiencies with respect to the protection of the confidentiality of information, as well as the divergence of the laws of countries on this matter, some international trade organizations have resorted to the preparation of several different model contracts according to the contracts they deal with, which include a typical confidentiality of information. For example, the practical guide for the elaboration of an orgalime know-how contract, Practical Guide for downstream users, article producers and article importers to understanding Regulation N 1907/2006 on the Registration, Evaluation, Authorisation of Chemicals (REACH) - May 2007, Last update October 2009. See ORGALIME GUIDES, orgalime, publications, model forms. Retrieved from https://publications.orgalime.org/ visited on 23/11/2018. Doris, M. (2014). Promising Options, Dead Ends and the Reform of Australian Contract Law. Legal Studies, 34(1), 36. Le Goff, P. (2007). Global Law: Legal Phenomenon Emerging from the Process of Globalization. Indiana Journal of Global Legal Studies, 14(1), 136-137. Coale, D. S. (2016). Commercial Litigation: 2014-2015. Texas Tech Law Review, 48(3), 591.
} 
have become complex, as their subjects are based on massive projects, and centred on complex operations full of technical and legal complexities. It is, therefore, not possible to conclude such contracts quickly and in a simple manner. Therefore, they need to be preceded by a phase of arduous negotiations.

Hence, negotiations are an important phase in the establishment of contracts, and as we have already explained, this phase is governed by the principle of contractual freedom and the principle of good faith, where cutting off of negotiations cannot in itself constitute a harmful act that requires tort liability. ${ }^{19}$ Therefore, negotiations may be revoked in accordance with the principle of will autonomy, which gives the negotiator who negotiates mala fide the opportunity to enter into negotiations for the purpose of obtaining professional, technical or technological secrets. In addition to this, there is a clear conflict between the interests of the negotiating parties. The negotiator possessing the confidential information is careful not to reveal any secret part of the information he possesses, while the other negotiator is willing to see some part of that confidential information in order to determine its truth and its economic value and suitability for purposes of contracting. However, in face of this conflict of interest is the commitment to maintain confidentiality in the pre-contracting phase. In both of the above cases, it is necessary to establish safeguards for the party possessing the confidential information in accordance with considerations of justice and legal logic in ensuring contractual economic equilibrium.

From another perspective, the obligation to maintain confidentiality of information during the negotiation phase is considered an

obligation which stems from the principle of good faith and is a direct reflection of the duty of disclosure. Otherwise, it does not

\footnotetext{
"le seul refus de poursuivre la vente ne suffit pas à caractériser une faute; que la liberté contractuelle implique celle de rompre les pourparlers, liberté qui n'est limitée que par l'abus du droit de rompre qui est une faute caractérisée par le fait de tromper la confiance du partenaire; que la cour d'appel, qui n'a relevé aucun élément à la charge de la société Blanc Colombe de nature à caractériser un tel comportement, contraire à la bonne foi contractuelle, a privé sa décision de toute base légale au regard de l'article 1382 du code civil". Légifrance, le service public de la diffusion du droit, French Court of Cassation, civil room 1, public sitting of Wednesday, 14 December 2016, no of appeal: 15-25352. Retrieved from https://www.legifrance.gouv.fr/affichJuriJudi.do?oldAction=rechExpJu riJudi\&idTexte $=$ JURITEXT000033631635\& fastReqId $=1809616963 \&$ fastPos $=2$ visited on $21 / 07 / 2018$.
} 
make sense to legally oblige a person to provide important and influential information to the other party in order to contract freely and in an enlightened manner, without requiring the latter to maintain confidentiality of the information between the parties. ${ }^{20}$

Eventually, however, the importance of enacting this obligation is more obvious in the context of the general theory of the Palestinian Civil Code Draft (PDCC) given the exceptional nature of the Palestinian context, ${ }^{21}$ i.e., the absence of any legal provision in the Palestinian laws-concerning intellectual property rights- obliging negotiating parties to maintain confidentiality of information.

\section{THE POSITION OF LEGISLATIONS AND LEGAL CONVENTIONS IN TERMS OF IMPOSING THE OBLIGATION TO CONFIDENTIALITY OF INFORMATION}

The position of comparative legislations differs in enacting the obligation to confidentiality of information as one of the main obligations in the pre-contracting phase as follows: for instance, as regards German law, the obligation to confidentiality of information in the German Civil Code is based on the obligation of care during the pre-contracting phase, ${ }^{22}$ where the second paragraph of Article 241 of the BGB states: "an obligation may also, depending on its contents, oblige each party to take account of the rights, legal interests and other interests of the other party". Therefore, Article 311 of the BGB states: "1- in order to create an obligation by legal transaction and to alter the contents of an obligation, a contract between the parties is necessary, unless otherwise provided by statute. 2- an obligation with duties under section 241 (2) also comes into existence by: Athe commencement of contract negotiations; B- the initiation of

See Saleh, supra note 6 at 486.

21 See Law of Trademarks No. 33 of 1952. Retrieved from http://muqtafi.birzeit.edu/ Legislation/GetLegFT.aspx?LegPath=1952\&MID=12149 visited on 20/11/2018. Law of Privileges of Inventions No. 22 of 1953. Retrieved from http://muqtafi.birzeit.edu/ Legislation/GetLegFT.aspx?LegPath=1953\&MID=1438 visited on 20/11/2018. Both of the mentioned legislations are considered outdated and need urgent amendment.

22 See Waldzus, D. (2014). Germany Pre-Contractual Disclosure Requirements and Relevant Case Law. International Journal of Franchising Law, 12(5), 3-4. Li, X. (2017). The Legal Status of Pre-Contractual Liability: Contrasting Responses from German and English Law. National Taiwan University Law Review, 12(1), 133-134. 
a contract where one party, with regard to a potential contractual relationship, gives the other party the possibility of affecting its rights, legal interests and other interests, or entrusts these to it, or C- similar business contacts".

Therefore, and from the above articles, the German legislature imposes on the negotiating parties the duty of care in respect of the interests of the other party, who offers him the possibility to make use of his rights. ${ }^{23}$ Hence, the duty of caution includes the negotiation phase of the contract, ${ }^{24}$ which requires that each negotiator maintains the confidentiality of information provided by the other party. Otherwise, the violation of the obligation to confidentiality of information entails obligating the violator to pay compensation for damages suffered by the injured party. ${ }^{25}$

In English law, nonetheless, the obligation to confidentiality of information in the pre-contracting phase found its legal basis in the theory of unjust enrichment, ${ }^{26}$ which provides that the party involved in the negotiation process is obliged to return what it has earned by its unfair actions at the pre-contracting phase. ${ }^{27}$ For example, if confidential information is disclosed or used after the failure of the negotiations, the rules of liability for the illicit gain of information will not be applied, since such information is obtained by lawful means, by its owner and his own free will. ${ }^{28}$ Rather, this is

23 Fischinger, P. S. (2010). Mobbing: The German Law of Bullying. Comparative Labor Law Policy Journal 32(1), 159-160.

24 See Al Mulla, A. (2017). The Principle of Good Faith in Contracts: Qatari Law Perspective. Asian Business Lawyer, 19, 127.

25 In accordance with the provisions of Article 280 et seq. Of the German Civil Code, Article 280 of the BGB states: "1- if the obligor breaches a duty arising from the obligation, the obligee may demand damages for the damage caused thereby. This does not apply if the obligor is not responsible for the breach of duty. 2- damages for delay in performance may be demanded by the obligee only subject to the additional requirement of section 286. 3- damages in lieu of performance may be demanded by the obligee only subject to the additional requirements of sections 281, 282 or 283". See Geier, A. (2014). Legal Representation of Clients with Diminished Legal Capacity in Germany. Journal of International Aging Law Policy 7, 19. Cardenas, J. (2013). Deal Jumping in Cross-Border Merger Acquisition Negotiations: Comparative Analysis of Pre-Contractual Liability under French, German, United Kingdom and United States Law. New York University Journal of Law and Business, 9(3), 963-965.

26 See Suleiman, A. S. (2008). Good Faith in Concluding Contracts. Amman, Jordan: Dar Dijla. 367.

27 Roach, G. P. (2007). How Restitution and Unjust Enrichment Can Improve Your Corporate Claim. Review of Litigation 26(2), 268-273.

28 See Wei, G. (2005). Breach of Confidence, Downstream Losses, Gains and Remedies. Singapore Journal of Legal Studies, 2005(1), 44. 
considered illicit enrichment, which leads to an obligation upon the negotiator (recipient of information) to return what he gained at the expense of the other negotiator as a result of using the confidential information.

Nevertheless, English law has given an extensive protection to information disclosed during the contract negotiation phase; besides the protection of trade-and-industry-related confidential information, this protection includes political, familial, personal and other secrets, since English law does not differentiate between the types of confidential information which are protected. ${ }^{29}$

However, the French legislature recently, turned to adopt a legal text obliging the negotiating parties to maintain confidentiality of information, otherwise they will be bound to tort liability in the general rules, where Article 1112-2 of the new French Civil Code, which was created by Decree N 131-2016 of 10 February 2016 (NFCC), states: "a person who without permission makes use of or discloses confidential information obtained in the course of negotiations incurs liability under the conditions set out by the general law". ${ }^{30}$

Nonetheless, prior to enacting this article, the French judiciary imposed an obligation to confidentiality of information on the grounds that the obligation of integrity imposed a mutual obligation on the parties to maintain confidentiality of information ${ }^{31}$ since disclosing it seriously harms one of the parties, or on the grounds of legal rules that protect the will from defects such as error, duress and

$29 \quad$ See Article 10 of The Trade Secrets (Enforcement, etc) Regulations 2018, Section 12 of the Human Rights Act of 1998, Articles 5-11 of the EU General Data Protection Regulation 2016/679, the Section of disclosure of information of the Freedom of Information Act 2000. See also Alsagher, supra note 11 at 121.

30 The original text in French is "celui qui utilise ou divulgue sans autorisation une information confidentielle obtenue à l'occasion des négociations engage sa responsabilité dans les conditions du droit commun". See Asfar-Cazenave, C. (2015). The New French Contract Law. Revue Juridique Themis, 49(3), 732.

31 See légifrance, le service public de la diffusion du droit, French Court of Cassation, social room, public sitting of Tuesday 8 December 2009, no of appeal: 08-17191. Retrieved from https://www.legifrance.gouv.fr/affichJuriJudi.do?oldAction=rechExpJuriJudi\& idTexte $=J$ JUITEXT000021472121\&fastReqId $=1811221752 \&$ fastPos $=1$ visited on $24 / 11 / 2018$. 
fraud,,$^{32}$ unfair competition suit. ${ }^{33}$ However, part of the jurisprudence and judiciary went on to regard the obligation to confidentiality as an obligation arising from the principle of good faith, which applies without the need for a legal text or agreement between the parties. ${ }^{34}$ Regardless of the multiplicity of legal rules, used by the French judiciary to determine the existence of the obligation to confidentiality of information, the researcher believes that the obligation to confidentiality of information is just a reflection of the duty of disclosure. Since, otherwise, it does not make any sense to legally oblige a party to provide substantial and influential information to the other party in order to contract freely and in an enlightened manner, without obliging the latter, in return, to maintain the confidentiality of information exchanged between the parties.

In order to promote such protection on an international scale, as the French legislation has emphasized, the UNIDROIT Principles of 2016 stressed the necessity to preserve the confidentiality of information provided in the negotiation phase, by refraining from disclosing or using that information. For instance, Article 2.1.16 of the UNIDROIT Principles of International Commercial Contracts 2016 states: "where information is given as confidential by one party in the course of negotiations, the other party is under a duty

32 Légifrance, le service public de la diffusion du droit, French Court of Cassation, commercial room, public sitting of Tuesday, 26 May 2009, no of appeal: 08-16240. Retrieved from https://www.legifrance.gouv.fr/affichJuriJudi.do?oldAction=rechExpJur iJudi\&idTexte $=$ JURITEXT000020684744\& fastReqId $=639725987 \&$ fastPos $=72$ visited on $24 / 11 / 2018$.

33 See légifrance, le service public de la diffusion du droit, French Court of Cassation, commercial room, public sitting of Tuesday 11 September 2012, no of appeal: 11-21322. Retrieved from https://www.legifrance.gouv.fr/affichJuriJudi.do?oldAction=rechExpJur iJudi\&idTexte $=$ JURITEXT000026375854\& fastReqId $=1747833485 \&$ fastPos $=2$ visited on 24/11/2018. Légifrance, le service public de la diffusion du droit, French Court of Cassation, commercial room, public sitting of Tuesday 17 March 2015, no of appeal: 1315862. Retrieved from https://www.legifrance.gouv.fr/affichJuriJudi.do?oldAction=rec hExpJuriJudi\&idTexte $=$ JURITEXT000030386043\& fastReqId $=734898701 \&$ fastPos $=1$ visited on 24/11/2018.

34 See légifrance, le service public de la diffusion du droit, French Court of Cassation, commercial room, public sitting of Tuesday 15 December 2015, no of appeal: 14-11500. Retrieved from https://www.legifrance.gouv.fr/affichJuriJudi.do?oldAction=rechExpJ uriJudi\&idTexte $=$ JURITEXT000031652185\&fastReqId $=76030935 \&$ fastPos $=1 \quad$ visited on 24/11/2018. Légifrance, le service public de la diffusion du droit, French Court of Cassation, civil room 1, public sitting of Monday 12 April 1976, no of appeal: 74-11730. Retrieved from https://www.legifrance.gouv.fr/affichJuriJudi.do?oldAction=rechExpJuri Judi\&idTexte $=$ JURITEXT000006996257\& fastReqId $=1501358316 \&$ fastPos $=63$ visited on 24/11/2018. See Aryan, S.; Mirabbasi, B. (2016). The Good Faith Principle and Its Consequences in Pre-contractual Period: Comparative Study on English and French Law. Journal of Politics and Law, 9(2), 240. 
not to disclose that information or to use it improperly for its own purposes, whether or not a contract is subsequently concluded;" thus, "where appropriate, the remedy for breach of that duty may include compensation based on the benefit received by the other party". ${ }^{35}$

\section{Therefore, legal jurists differed in determining the legal basis on} which the UNIDROIT Principles were based in determining the existence of this obligation. In light of this, some attributed this to the theory of unjust enrichment, while others considered that the principles of the UNIDROIT were based on the provisions of tort liability in enacting the obligation to confidentiality of information. ${ }^{36}$ A third trend, however, chose to refer to the principles of good faith and what is required by the integrity of dealing between the

35 In this regard, the TRIPS Convention for Trade-Related Aspects of Intellectual Property Rights, in its Article 39 provides that: "1- in the course of ensuring effective protection against unfair competition as provided in Article 10bis of the Paris Convention (1967), Members shall protect undisclosed information in accordance with paragraph 2 and data submitted to governments or governmental agencies in accordance with paragraph 3.

2- Natural and legal persons shall have the possibility of preventing information lawfully within their control from being disclosed to, acquired by, or used by others without their consent in a manner contrary to honest commercial practices 1 so long as such information:

a- is secret in the sense that it is not, as a body or in the precise configuration and assembly of its components, generally known among or readily accessible to persons within the circles that normally deal with the kind of information in question;

$b$ - has commercial value because it is secret; and

$c$ - has been subject to reasonable steps under the circumstances, by the person lawfully in control of the information, to keep it secret.

3- Members, when requiring, as a condition of approving the marketing of pharmaceutical or of agricultural chemical products which utilize new chemical entities, the submission of undisclosed test or other data, the origination of which involves a considerable effort, shall protect such data against unfair commercial use. In addition, Members shall protect such data against disclosure, except where necessary to protect the public or unless steps are taken to ensure that the data are protected against unfair commercial use". It is clear from the text of article 39 of the TRIPS Convention that it has imposed the obligation not to disclose confidential information or use it by parties to the contract / negotiation without prior authorization from the possessor of this information. However, such information shall be considered confidential with the meeting of three basic conditions: the identification of the concept of confidential information should be achieved, the fact that such information has a commercial value resulting from its confidentiality, and that the possessor of such information shall follow the necessary legal procedures to maintain its confidentiality. Besides that, it should be noted that the TRIPS Convention imposes on all member States of the International Trade Organization (WTO) to regulate this matter in their domestic law on the basis of article 1 of the Convention. See Shabalala, D. (2017). Access to Trade Secret Environmental Information: Are Trips and Trips-plus Obligations Hidden Timeline. Columbia Journal of Transnational Law 55(3), 692. Mace, A. C. (2009). TRIPS, E-Bay, and Denials of Injunctive Relief: Is Article 31 Compliance Everything. Columbia Science and Technology Law Review, 10, 241.

36 See Suleiman, supra note 22 at 365. 
negotiating parties. ${ }^{37}$ These jurisprudential views will be examined in detail when discussing the position of the PDCC on this obligation as follows.

As for Palestinian legislations, we find that the PDCC is devoid of any provisions governing the contractual negotiation phase or any provisions imposing the obligation of behaving in good faith at this phase, or any provision imposing the duty of disclosure and information as mentioned, or the obligation to confidentiality of information. ${ }^{38}$ In light of this, the jurisprudence is based on many other theories and legal principles to say that there is an obligation to confidentiality in the pre-contracting phase, the most important of which are the following:

\section{The Provisions of Tort Liability}

Part of the legal jurisprudence went on to consider the provisions of tort liability as the legal basis for imposing the obligation to maintain the confidentiality of information, on the grounds of the absence of any contract governing the matter (the negotiation phase), and on the foundation that the disclosure or use of confidential information without the prior authorisation of the possessor constituted a breach of a general obligation of the law, which is not to cause harm to others. ${ }^{39}$ Accordingly, this opinion hinges on the legal basis for the obligation to maintain the confidentiality of information as a legal obligation to the rules of tort, and; therefore, whether there

37 See van Houtte, H. (2014). Contract Negotiations and the Unidroit Principles. Uniform Law Review, 19(4), 554. Nahan, N. (2015). Duty of Confidence Revisited: The Protection of Confidential Information. University of Western Australia Law Review, 39(2), 279-280.

38 In this regard, the position of the Palestinian legislature is identical to that of the Jordanian and Egyptian legislatures, where the civil codes of both countries are voided of any legal provisions that imposes a commitment to confidentiality of information. However, the Egyptian Commerce Code states in Article 83 that: "1- the importer shall be bound to maintain the confidentiality of the technology obtained, the confidentiality of the improvements occurring upon the, and shall be responsible to compensate the damages resulting from the disclosure of such confidentiality, whether it takes place at the negotiation stage of the contract or thereafter.

2- Likewise, the supplier is also obliged to maintain the confidentiality of the improvements occurring upon them by the importer and transfers them to him under a condition in the contract, and he shall be responsible to compensate for damage caused by disclosure of such confidentiality".

39 See Aldsouki, I. M. (1995). Legal Aspects of Negotiations Management and Conclusion of Contract. Riyadh, Saudi Arabia: General Administration of Research. 98. Abdul Rahman A. F. (2010). Technology Transfer Contract in the New Commerce Code. Cairo, Egypt: Dar Alnahdah Alearabiah. 44. 
is an agreement between the negotiating parties to be bound by confidentiality or not, liability will emerge in case of disclosure or use of information. ${ }^{40}$

One of the most prominent judicial judgments in support of this opinion is the ruling of the USA Federal Supreme Court in a case of Galanis v Procter and Gamble, the facts of which are as follows: Ms. Galanis sent a letter to Procter company telling them about an idea she had developed that would improve their detergent for cleaning cloths, but Procter company responded with an apology, since it used comparable ideas without success. After a period of time there appeared in the market a cleaning powder named Blue Sherar, and this product was based on the idea by Ms. Galanis, which had achieved huge commercial success. As a result, Ms. Galanis filed a lawsuit against Procter and Gamble based on the negotiations that occurred between them and during which Ms. Galanis disclosed the information. However, the court ruled that Procter and Gamble had breached its obligation to maintain the confidentiality of the information, where Ms. Galanis would not have disclosed the secret of the powder composition except for the purpose of obtaining benefits through contracting; therefore, the court determined Procter and Gamble's liability on the basis of tort liability. ${ }^{41}$

However, referring to the PDCC, we find that: firstly, the provisions of tort liability cannot be a legal basis for the obligation to maintain the confidentiality of information, and the most obvious evidence for this is that the text of article 179 of the PDCC deals with the positive act without the negative act, while the tortious liability ensues in both cases of a positive and negative act if it causes damage, which means that the disclosure or use of information in a method of a negative act does not entail any liability. ${ }^{42}$ Secondly, the legal basis for requiring the injured party to compensate for the

40 See Alkalioubi, S. (2007). Al-Wasit in Explaining the Egyptian Commerce Code, Commitments, Commercial Contracts and Operations of Banks. Cairo, Egypt: Dar Alnahdah Alearabiah. 86.

41 Galanis v. Procter and Gamble Corporation, 153 F. Supp. 34 (S.D.N.Y. 1957). See Olsson Jr, Harry R. (1958). Dreams for Sale: Some Observations on the Law of Idea Submissions and Problems Arising Therefrom. Law and Contemporary Problems, 23(1), 37. Mishal, M. S. (2003). The Legal protection of Technical knowledge (Unpublished Doctoral Dissertation). Nahrain University Baghdad, Iraq. 42.

42 Article 179 of the PDCC states: "anyone who has committed an act that caused damage to others is obliged to compensate for it". 
disclosure or use of confidential information in the pre-contracting negotiations is not because the other negotiator has violated the obligation of maintaining the confidentiality of information; but, rather, on the basis of his tort liability for the damage caused by his action. This is so since there is no legal provision in the PDCC requiring him to maintain the confidentiality of information. Besides that, the application of the provisions of tort liability to disclose or use confidential information will result in compensating the injured negotiator for the loss of profits, which is difficult to be accepted at the negotiation phase..$^{43}$

\section{The Principle of Good Faith}

Another part of the legal jurisprudence believes that the legal basis for the obligation to maintain the confidentiality of information in the negotiation phase (the pre-contracting phase) refers to the principle of good faith and what is required by the integrity of dealing between the negotiating parties. ${ }^{44}$ In this regard, the most important requirement for contracting in good faith is to avoid anything that would adversely affect the conclusion of the contract, whether this act is positive or negative. ${ }^{45}$ Moreover, this part of the jurisprudence believes that the principle of good faith is divided into two requisite obligations: first, the duty of disclosure and information and, second, the obligation to preserve the confidentiality of the information disclosed during negotiations, which is a natural and inevitable consequence of the duty to disclosure. ${ }^{46}$

Hence, it is clear that the function of the principle of good faith at the negotiations phase is to achieve a balance between the

43 See Lutfi, H. M. (1995). Civil Responsibility in the Negotiation Phase, A Study in Egyptian and French Law. Cairo, Egypt: Al-Nacre Al-Dahabieh. 90.

44 See Abdel Aal, H. M. (1998). The Conventional Organization of Contractual Negotiations. Cairo, Egypt: Dar Alnahdah Alearabiah. 119. Aryan; Mirabbasi, supra note 30 at 240. Finkin, M. W. (2017). Chapter 7: Privacy and Autonomy. Employee Rights and Employment Policy Journal, 21(2), 610.

45 See Ali, H. W. (2010). Good Faith in International Sales, An Analytical Comparative Study in Light of International Conventions and Comparative Legislation. Cairo, Egypt: Dar Alnahdah Alearabiah. 366.

46 See Ibrahim, M. A. (2006). Good Faith in Contracts. Beirut, Lebanon: Zain Legal Publications. 3. Abdellah, Z. A. (2009). The Legal Protection of Trade Secrets in Technology Transfer Contracts. Cairo, Egypt: Dar Alnahdah Alearabiah. 110-111. Hwang, C. (2018). Deal Momentum. UCLA Law Review, 65(2), 397. White, A. M. (2017). Foreclosure Diversion and Mediation in the States. Georgia State University Law Review, 33(2), 439-440. 
negotiating parties, by obliging each party to provide its information in an explicit manner, and to grant the injured party the right to claim compensation. ${ }^{47}$ As a result, the principle of good faith in the negotiations phase requires the recipient of the confidential information to maintain the confidentiality of that information during the negotiations phase, ${ }^{48}$ and, not only that, but it also requires positive conduct to facilitate cooperation among them, in order to conclude the contract and implement it subsequently. ${ }^{49}$ Ultimately, the jurists of this approach consider the liability for violating the obligation of confidentiality as tort liability; of course, this is in the absence of an agreement between the negotiating parties, which obligates them to maintain the confidentiality of information.

However, the legal basis for the obligation of maintaining the confidentiality of information based on the principle of good faith cannot be established for several reasons: firstly, the principle of good faith is a general norm, which has a broad meaning, with no specific or disciplined definition. ${ }^{50}$ Subsequently, it is not possible to rely on a general principle that can be interpreted in determining the legal basis for the obligation of confidentiality of information at the negotiations phase, especially in the absence of any legal provisions that oblige the parties to negotiate in good faith in the PDCC.

Secondly, the idea of good faith and trust in dealings represents a point of contact between law and morals. It cannot be denied that the principle of good faith is moral in nature. Thus, the criterion for ascertaining a person's responsibility in accordance with this principle is based on the standard of conduct of the ordinary person in the same circumstances, and on the moral aspect exceeding the legal aspect of the subject of non-breach of negotiations. ${ }^{51}$

\footnotetext{
$47 \quad$ Ali, supra note 41 at 318.

48 See Abdellah, supra note 42 at 111. Al Mulla, supra note 20 at 131.

49 See Ahmed, J. K. (2003). Obligation to inform in Pre-Contracting. Cairo, Egypt: Dar Alnahdah Alearabiah. 82. Angheni, S. (2017). General Considerations on the Contract as the Main Source of Legal Liability between Traders. Law Annals from Titu Maiorescu University, 2017, 9. Mandelbaum, J.; Swartz, S.; Hauert, J. (2016). Periodic Review in Natural Resource Contracts. Journal of Sustainable Development Law and Policy, 7(1), 132.

50 See Sarii-Aldiyn, S. H. (2001). Technology Transfer Contract in the New Commerce Code. Cairo, Egypt: Dar Alnahdah Alearabiah. 15.

51 Abu El-Nemer, E. (2002). Negotiations of International Trade Contracts. Alharam, Egypt: Dar Abu El-Magd. 146.
} 


\section{Implicit Contract between Negotiating Parties}

This jurisprudential trend is based on the idea of an implicit contract as a legal basis for the obligation to maintain the confidentiality of information disclosed during the negotiations. ${ }^{52}$ Therefore, this approach assumes that the negotiation takes place in all cases based on previous agreement between the parties, whether this agreement is explicit or implicit, the negotiation of the contract is always of a contractual nature. ${ }^{53}$ In other words, if two parties decide to enter into negotiations in order to conclude a specific contract, they have certainly documented each other and reached opposite points of view prior to the actual serious entry into the subject of the negotiations and the presentation of issues and points of secrecy. ${ }^{54} \mathrm{It}$ is unreasonable that one of the negotiating parties presents details of the confidential information without taking the assurances that they will not be disclosed or used in case of failure of the negotiations. Consequently, this implicit contract between the negotiators binds the receiver to maintain the confidential information.

This trend justifies the result which they, the legal jurists, have arrived at based on the following justifications: firstly, negotiations are the result of deliberate preliminary agreements, not mere coincidence, as it is inconceivable that the parties to the negotiations suddenly found themselves negotiating a contract; secondly, the objective of the negotiating parties from the outset is to make a legal effect. Once they accept entering negotiations, they agree at the same time to contract in principle, and the only thing left is to agree on the details of the contract so that it could be concluded in its final form..$^{55}$ Thirdly, once the negotiators enter into negotiations, a special relationship arises between them, which entail certain obligations. This contractual relationship is to enter into the negotiations, respect them, and to not disclose confidential information; now, whether they are explicitly or implicitly in agreement, they express this, that both of them have become creditors and debtors to one another. ${ }^{56}$

\footnotetext{
$52 \quad$ See Abdellah, K. R. (2000). Negotiate the Contract. Cairo, Egypt: Dar Alnahdah Alearabiah. 468.

53 See Ashour, J. M. (2010). Technology Investment Contract. Beirut, Lebanon: Al-Halabi Legal Publications. 329-330.

54 Abu El-Nemer, supra note 47 at 202.

55 See Abdellah, supra note 42 at 160.

56 Abu El-Nemer, supra note 47 at 203-204.
} 
Based on the above, the obligation to maintain the confidentiality of the information at the pre-contracting phase is based on the idea of an implicit contract, and if one negotiator disrupts this obligation, he will bear the contractual liability. ${ }^{57}$ Nevertheless, we cannot accept this approach and adopt it as a basis for the obligation of the confidentiality of information at the pre-contracting phase for several reasons, the most important of which are:

First, contractual liability is confined to the contract in the legal sense known to the term, which is the correlation of the offer with the acceptance by two clear wills (the will of both parties; hence, the use of the plural "wills" in italics) to conclude the contract, and to achieve the legal consequences resulting from it, and therefore this will (the will of the one of the parties) cannot be assumed in existence in any other way. ${ }^{58}$

Second, assuming the validity of their presumption that there is an implicit contract -that imposes the obligation to maintain the confidentiality of the information, another obstacle will be found in the manner of proving the presence of this contract before the law and the judiciary; there must be evidence and proofs on which to base the judgment. ${ }^{59}$ Thus, this is inconceivable in the case of presumption of an implicit contract, on the bases of which the recipient of the information is obliged to maintain its confidentiality. Eventually, having analysed the most important jurisprudential approaches to the subject of the legal basis of the obligation to confidentiality of information in the pre-contracting phase, we find that it does not serve as a legal basis for the subject of this obligation in the PDCC. This is so as the PDCC is devoid of any provisions governing the contractual negotiation phase. It is convincing, however, that the obligation to maintain the confidentiality of information during the negotiation phase is an obligation which stems from the principle of good faith and is a direct reflection of the duty of disclosure. Nonetheless, it is not logical to legally oblige a party to provide important information to the other party in order to contract freely and in an enlightened manner, without requiring the latter to maintain the confidentiality of information between the parties.

\footnotetext{
See Melhem, H. S. (2005). Negotiating Contracts Through the Internet. Nahrain University Journal 13(8), 110.

58 See Ashour, supra note 49 at 330.

59 See Lutfi, supra note 39 at 41-42.
} 
However, in addition to the absence of any legal provision that requires parties in the pre-contract phase to behave in good faith or impose the duty of disclosure, the intellectual property codes do not have any legal article which obliges the parties to maintain the confidentiality of information. Hence, the Palestinian legislature must intervene urgently to enact a legal text obliging the negotiating parties to maintain confidentiality of the information exchanged during negotiations within the scope of the general theory of civil code. This is so in order to solve any juridical or juristic dispute that may arise regarding the current status of the PDCC. Moreover, it is also to let the obligation to maintain the confidentiality of information turn into a general legal obligation and; thus, become a presumed obligation by the force of law, whether or not the contract is concluded and whether the parties agree upon it or not.

Therefore, this does not mean that the obligation to maintain the confidentiality of information is an absolute duty. However, there should be some determinants to say that one of the negotiating parties has violated this obligation, which is set as follows.

\section{SUGGESTED ORIENTATIONS FOR THE FORMULATION OF TERMS AND PROVISIONS OF THE OBLIGATION TO MAINTAIN CONFIDENTIALITY OF INFORMATION IN THE PDCC}

The obligation to maintain confidentiality of information during the pre-contracting phase is a relative obligation; meaning, it has its own set of limitations and restrictions. These limitations and restrictions concern both: the claim of its existence or the claim that it has been violated by a negotiating party. Thus, it is necessary to determine the extent to which the debtor has the obligation to maintain the confidentiality of information and not to disclose or use it. Moreover, the scope of time during which the negotiator remains obliged to maintain the confidentiality of such information should also be determined. Also, it is obvious that the negotiation process is not limited to the person willing to negotiate, but also includes some experts, which requires determining the scope of persons legally required not to disclose or use such confidential information. 


\section{Scope of Obligation to Maintain Confidentiality of Information in Terms of Subject Matter}

The purpose of determining the scope of the obligation to maintain confidentiality of the information in question is to identify the confidential part of the information exchanged between the parties during the negotiation, so as to inform the recipient party of that information and to bind him not to disclose or use it. In light of this, the majority of the legal jurisprudence went on to say that the scope of the obligation to maintain confidentiality of information is limited to two kinds of information: the first type relates to the information to which the owner ascribed the character of confidentiality ${ }^{60}$ In a precise sense, it is the information that is characterized by a nature of confidentiality in particular, as this information is not prepared for the access of or disclosure to others, but has been disclosed according to the requirements of the existing negotiation process. With respect to this type of information, the legal doctrine differed, and three different opinions have been developed:

1. The first opinion limits this confidentiality of information to information which are exclusively disclosed by those concerned, the disclosure or use of which entails damages, and the general criterion in determining them is the mutual trust between the parties in relation to the negotiated contract. ${ }^{61}$ Examples of this type of information includes: a formula, pattern, compilation, program, device, method, process, or technique, and information relating to the financial situation of a party.

2. The second opinion considers that the information included in the obligation of the recipient to maintain confidentiality is all technical or technological information known by accident or through examination and scrutiny. ${ }^{62}$ Especially so, if this information is not intended for disclosure, i.e. information that is not available to the recipient of the information except through negotiation or because of it.

60 See Al-Mahdi, M. N. (2009). The Professional Contracting Party, its Concept, Obligations and Liability, A Comparative Study. Cairo, Egypt: Dar Alnahdah Alearabiah. 130.

${ }_{61} \quad$ See Lutfi, supra note 39 at 31.

62 See Jamal, M. (2002). The Willingness of Contracting. Beirut, Lebanon: Al-Halabi Legal Publications. 415. 
3. The third opinion considers that the information included in the obligation of the recipient to maintain confidentiality is all the information and technical data that has been disclosed during the negotiations regardless of how it reaches the recipient's knowledge, and the recipient is committed to maintaining its confidentiality in the same degree as he maintains the confidentiality of his own rights. ${ }^{63}$

However, in all prior cases of jurisprudential opinions, confidential information should be identified in a precise and unambiguous manner, especially since this information is not confidential by its nature; rather, it is the possessor who gives it a confidential nature. This is what the Palestinian legislature should take into account. ${ }^{64}$

The second type, however, relates to the information that is inherently confidential. Therefore, it includes all the information that its prevalence may cause harm to the other party, whatever this damage is. ${ }^{65}$ This type of information includes, in particular, information of a personal or private nature and the right to privacy for example, ${ }^{66}$ and here, the recipient of such information is committed not to disclose or use it for personal considerations, not for commercial and economic considerations as in the first type.

Nevertheless, it is clear that the confidentiality of the information does not include the information that the negotiator had before entering the negotiations, since it has been discovered or known independently of the negotiations. ${ }^{67}$ Besides that, ascribing confidentiality to some information may itself be unlawful, for example because it conflicts

63 See Abu El-Nemer, supra note 47 at 206.

64 See légifrance, le service public de la diffusion du droit, French Court of Cassation, commercial room, public sitting of Wednesday 18 October 2017, no of appeal: 16-15891 16-15903. Retrieved from https://www.legifrance.gouv.fr/affichJuriJudi.do?oldAction= rechExpJuriJudi\&idTexte $=$ JURITEXT000035850159\&fastReqId $=1131035221 \&$ fastP os $=2$ 26/11/2018.

65 See Aldsouki, supra note 35 at 102.

66 See Al-Mahdi, supra note 56 at 17.

67 Article 1112-2 of the new French Civil Code, which was created by Decree N 131-2016 of 10 February 2016, (hereinafter 'NFCC'), states: "a person who without permission makes use of or discloses confidential information obtained in the course of negotiations ...". 
with public order, the law provides for a certain type of information that should not be confidential. ${ }^{68}$

From the researchers' point of view, the possessor of the confidential information must be cautious as to oblige the negotiating parties who negotiate with him not to disclose any information of a nature of which is confidential, or which is described as such by the possessor himself-by concluding an agreement specifying the confidential information, and imposing the obligation of confidentiality of the exchanged information on the recipients of that information and so on. ${ }^{69}$

\section{Scope of Obligation to Maintain Confidentiality of Information in Terms of Individuals}

The negotiation process requires the intervention of a number of experts, especially if the subject or content of the contract is a complex technology or technique. However, these experts will undoubtedly be informed of the secrets of the technology. Therefore, the obligation to maintain the confidentiality of the information in this case is not limited to the direct negotiator of the contract to be concluded, but extends to include persons who entered the negotiations in one way or another. ${ }^{70}$

68 For example, Article 11 of the Palestinian Law No. (21) of 2005 Concerning Consumer Protection states that: "in the event it is proven to the supplier that the goods or services, which he has offered for trading, implies one or more defect(s) that may affect consumer's safety or health or which may pose a hazard to him, the supplier must immediately take the following measures: 1-notify the competent authorities and inform the public by means of the mass media about such defects as well as warn against the hazards which may result therefrom. 2- withdraw the goods from the market. 3-restore the goods which have been sold or leased and refund the price paid. 4- replace the goods at his own expense and refund the paid price in the event their maintenance is unattainable. 5- get rid of them using sound and environment-friendly techniques at his own expense". Therefore, if the negotiator knows during the negotiations that the goods or services contain a defect, that harms the safety of the consumer for example, he must inform the competent authorities, even if there is an agreement between them to maintain the confidentiality of information disclosed.

69 See légifrance, le service public de la diffusion du droit, French Court of Cassation, civil room 1, public sitting of Wednesday 1 June 2016, no of appeal: 15-13221. Retrieved from https://www.legifrance.gouv.fr/affichJuriJudi.do?oldAction=rechExpJuriJudi\&idTexte=J URITEXT000032635842\& fastReqId $=289559670 \&$ fastPos $=18$ visited on 27/11/2018.

70 See Telep, J. M.; Cohen, J. Y. (2011). FinCen Publishes Final Rule and Interpretive Guidance Clarifying the Scope of Sar's Confidentiality Provisions. Banking Law Journal, 128(3), 228-229. See légifrance, le service public de la diffusion du droit, French Court of Cassation, civil room 1, public sitting of Wednesday 1 June 2016, no of appeal: 15-16486. Retrieved from 
Consequently, the obligation to maintain confidentiality in negotiations is not limited to the recipient of confidential information, but extends to associates of the information's recipients, such as workers, technicians, experts and consultants. It also extends to the person(s) with whom they are associated through a contract of employment, such as the person(s) they have chosen to assist and advise in the negotiation process; in addition to, persons who are considered to be on the part of the recipient and his nascent companies, ${ }^{71}$ and whoever participates in the contract even if incidentally. ${ }^{72}$

However, the possessor of the confidential information may take certain precautionary measures in order to protect confidential information, such as expressly stating in the agreement between him and the recipient of such information, that the recipient of confidential information may not disclose it to third parties, even to experts, prior to obtaining authorisation from the possessor. In effect, such an agreement may limit and restrict the possibility of transferring information to third parties, which also entails the possibility of concluding a confidentiality agreement with third parties (experts or others), for those to whom the information is likely to be transferred. ${ }^{73}$

Accordingly, the Palestinian legislature should take into account, when drafting the legal article imposing the obligation to maintain confidentiality of information during the negotiations, not only to oblige the negotiators, but also to impose the obligation on everyone

https://www.legifrance.gouv.fr/affichJuriJudi.do?oldAction=rechExpJuriJudi\&idTexte= URITEXT000032637090\& fastReqId $=1321411029 \&$ fastPos $=6$ visited on 27/11/2018.

71 See Abu El-Nemer, supra note 47 at 109.

72 See légifrance, le service public de la diffusion du droit, French Court of Cassation, commercial room, public sitting of Wednesday 28 March 2018, no of appeal: 1620018. Retrieved from https://www.legifrance.gouv.fr/affichJuriJudi.do?oldAction=r echExpJuriJudi\&idTexte=JURITEXT000036780076\&fastReqId $=1097017314 \&$ fastP os $=1$ 29/11/2018. Légifrance, le service public de la diffusion du droit, French Court of Cassation, commercial room, public sitting of Wednesday 18 October 2017, no of appeal: 16-15900. Retrieved from https://www.legifrance.gouv.fr/affichJuriJudi.do?oldAction= rechExpJuriJudi\&idTexte $=$ JURITEXT000035850176\&fastReqId $=1003148514 \&$ fastP os $=2$ visited on 29/11/2018. Légifrance, le service public de la diffusion du droit, French Court of Cassation, civil room 3, public sitting of Thursday 27 April 2017, no of appeal: 16-11689. Retrieved from https://www.legifrance.gouv.fr/affichJuriJudi.do?oldAction= rechExpJuriJudi\&idTexte $=$ JURITEXT000034554626\&fastReqId $=1685607540 \&$ fastP os $=5$ visited on $29 / 11 / 2018$.

73 Davis, R. M. (2010). Trimming the Judicial Oak: Rule 10b5-2(b)(1), Confidentiality Agreements, and the Proper Scope of Insider Trading Liability. Vanderbilt Law Review, 63(5), 1494. 
who is aware of the confidential information through negotiation or because of it, by refraining from disclosing or using the confidential information. ${ }^{74}$

\section{Scope of Obligation to Maintain Confidentiality of Information in Terms of Time}

The obligation to maintain the confidentiality of information in the pre-contracting phase requires that the recipient of confidential information maintains (not to disclose or use) confidential information and it is not sufficient to claim that he has made every effort to preserve these secrets. ${ }^{75}$ However, regardless of the knowledge or identification of the party that cause the termination of the negotiations and their failure, the issue arises in the period of time during which this obligation remains in force. More precisely, in other words, what is the extent to which the obligation of the recipient of confidential information to maintain the confidentiality of such information is still applicable in terms of time, especially as the results of negotiations on contracts are only a potential, i.e. the parties to the negotiations may reach a final contract and the negotiations may fail. Therefore, does the obligation to maintain the confidentiality of information end once the final contract has been concluded? Or once negotiations fail? Or does it go on indefinitely? The French legislature did not resolve this issue when it enacted the obligation to maintain the Confidentiality of Information in the Article 1112-2 of the NFCC. In view of this, four legal jurisprudential trends emerged, which are:

1. The first jurisprudential trend states that the obligation to maintain the confidentiality of information is an eternal obligation that has no time limits. ${ }^{76}$ As such, the information that is considered confidential does not lose this nature unless it reaches public knowledge without the debtor's maintaining of the confidentiality obligation being the reason for that, i.e. without the recipient of confidential information having breached his obligation to the confidentiality of information.

\footnotetext{
74 The Palestinian legislature is advised to view the Formulation of Article 1112-2 of the NFCC.

75 See the text of Article 1112-2 of the NFCC.

76 See Jalloul, S. S. (2009). Practical Knowledge, Study in Concept, Contracts and Methods of Protection. Beirut, Lebanon: Al-Halabi Legal Publications. 361.
} 
The second jurisprudence trend states that the former trend, which makes the obligation to maintain the confidentiality of information as an eternal obligation without time limits, is an excessive trend owing to the protection of confidentiality in terms of time, up to an unacceptable extent. Thus, this obligation must be limited to a sensible stretch of time. Consequently, this trend is justifying the necessity to define the time frame of this obligation by the fact that French law does not accept the conception of perpetual obligations, in addition to the velocity of scientific and technological developments as a further justification. It is, therefore, sufficient to limit the period of this obligation to a period of 5-10 years as an adequate period to protect the confidentiality of information. ${ }^{77}$

2. The third trend suggests that an appropriate period should be set for the termination of the obligation to maintain the confidentiality of the information disclosed, without specifying a certain extent as the second trend. ${ }^{78}$ It is also possible to stipulate that the obligation to secrecy should be terminated if confidentiality is lost for reasons not attributable to the recipient of the confidential information.

3. The fourth trend states that the duration of the obligation to maintain the confidentiality of information can be determined based on the criterion of economic and commercial importance of the confidential information. ${ }^{79}$ Therefrom, the negotiator shall be considered to be violating his obligation to maintain the confidentiality of information whenever he discloses or uses such information while it still has an economic or commercial value.

Regardless of whatever the four jurisprudential trends stated, the Palestinian legislature should state that the obligation to maintain the confidentiality of information remains binding as long as the nature of this information is kept confidential. ${ }^{80}$ This does not in any way imply that this obligation remains eternal, since what is today a secret is not the same tomorrow. Moreover, the laws have a certain

See Abu El-Nemer, supra note 47 at 68.

See Abdellah, supra note 42 at 309.

See Mohammedine, supra note 9 at 72.

See Sarii-Aldiyn, supra note 46 at 76. 
period for the exploitation of important confidential information such as patents, technical information, formulas or industrial patterns to ensure their confidentiality and; thus, the public has the right to use, access or disclose them without the prior permission of the possessor.

Another problem which emerges clearly, however, is the determination of the criterion by which the judge can rule that the recipient of confidential information has violated his obligation to maintain the confidentiality of information. In light of this, the Palestinian legislature can rely on the extent of the knowledge of third parties or the degree of their knowledge of the confidential information as a criterion for disclosure of the confidentiality of information. ${ }^{81}$ In this respect, the French Court of Cassation ruled that: publishing is sufficient in the case of distribution of brochures to customers explaining the content of information so that it suffices to just look at it for the professional to know the method and subject of manufacture. ${ }^{82}$

\section{Proving the Obligation to Maintain Confidentiality and the Penalty for Violation of this Obligation}

In relation to proving the violation of the obligation to maintain the confidentiality of information which places on the person, who claims such revealing or using of the confidential information, the burden of proving such violation and the damages caused by it, which should be adopted by the Palestinian legislature in enacting the obligation of maintaining the confidentiality of information in the pre-contracting phase. Therefore, the plaintiff must prove the breach of the obligation of confidentiality and the damages suffered as a result of that, and that such damages are caused by this breach. ${ }^{83}$

81 See Al-Mawla, K. N. (2003). The Legal Effects of Technology Transfer Contracts. Amman, Jordan: Dar Wael for Publishing \& Distribution. 179.

82 See Mishal, Supra note 37 at 40. See légifrance, le service public de la diffusion du droit, French Court of Cassation, commercial room, public sitting of Wednesday 14 November 2018, no of appeal: 16-22845. Retrieved from https://www.legifrance.gouv. fr/affichJuriJudi.do?oldAction $=$ rechExpJuriJudi\&idTexte $=$ JURITEXT000037644590\& $\mathrm{f}$ astReqId $=907237637 \&$ fastPos $=1$ visited on 29/11/2018.

83 "Les partenaires d'une négociation, relative à une cession de parts sociales, sont tenus d'un devoir de loyauté qui repose sur la bonne foi et qui les oblige à respecter leurs engagements pré-contractuels de confidentialité. Ce devoir ne disparaît pas du fait de l'échec des pourparlers. Cependant, ne constitue pas une faute le fait d'informer le principal fournisseur de la société cédante de la démission de son gérant, la 
Therefore, the liability arising from the violation of the obligation to maintain the confidentiality of information is a tort liability, since the obligation to maintain the confidentiality of information often comes in the pre-contracting phase. Besides that, if the Palestinian legislature enacts this obligation in a legal article, the violation of the obligation to maintain the confidentiality of information is a breach of a legal duty, not of a contractual obligation. Therefore, the elements of tort liability must exist to claim compensation. Nevertheless, this rule only applies in the absence of any agreement obliging the negotiating parties to preserve the confidential information disclosed, which requires the application of contractual liability.

\section{CONCLUSION}

The importance of enacting and regulating a legal provision concerning the obligation to maintain the confidentiality of information in the pre-contracting phase lies in its role in ensuring the establishment of contracts in a balanced manner, economically and contractually, and in conformity with the requirements of modern contractual justice. However, the Palestinian legislature does not provide any legal provisions imposing upon the negotiating parties to maintain the confidential information disclosed during the negotiation phase.

société s'étant contentée de faire état d'une information n'ayant aucun caractère de confidentialité, la démission d'un gérant faisant l'objet d'une publication, et l'on voit mal comment une telle information aurait pu demeurer secrète, compte tenu des relations entretenues par le fournisseur et son client. S'agissant du fait d'informer ce même fournisseur de son intention d'acquérir les parts sociales, il appartient à la requérante de démontrer, à supposer la violation de l'engagement de confidentialité retenue, que cette information lui a causé un préjudice, les allégations, non prouvées, sur une perte supposée de clientèle consécutivement à cette révélation étant insuffisantes, étant observé que le fournisseur n'entretenait aucun rapport de concurrence avec elle". See légifrance, le service public de la diffusion du droit, Lyon Court of Appeal, public sitting of Thursday 20 January 2005, no. of appeal 03/03119. Retrieved from https://www.legifrance.gouv.fr/ affichJuriJudi.do?oldAction=rechExpJuriJudi\&idTexte $=$ JURITEXT000006944634\&fas tReqId=628913753\&fastPos=2 29/11/2018. Légifrance, le service public de la diffusion du droit, Lyon Court of Appeal, civil room 3, public sitting of Thursday 9 March 2006, no of appeal 04/04968. Retrieved from https://www.legifrance.gouv.fr/affichJuriJudi.do?old Action $=$ rechExpJuriJudi\&idTexte $=$ JURITEXT000006949155\& fastReqId $=560881028 \&$ fastPos=1 visited on 29/11/2018. 
In light of the foregoing analyses and explanation of the concept, its importance, function and legal basis and the suggested orientations for the formulation of the terms and provisions of the obligation to maintain the confidentiality of information, it has become evident that the traditional theories of the implicit contract between the negotiating parties along with the principle of good faith and the provisions of tort liability in the PDCC are not enough to ensure contractual equilibrium. Thus, this necessarily entails that the obligation to maintain the confidentiality of information has its own independent essence from all the theories that the jurisprudence adopted as a legal basis for this obligation. Thus, it is clear that the significance of passing a legislative text obliging the contracting parties in the pre-contracting phase to commit to the confidentiality of information, as a legal means through which the Palestinian legislature can solve the cognitive imbalance between the negotiating parties in the field of commercial and civil transactions, and as a means of ensuring that the creditor of the duty of disclosure and information performs his duty in the best possible manner, in order to reach a stage of ensuring contractual justice.

Therefore, in reviewing and analysing the terms and provisions of the obligation to maintain the confidentiality of information in the NFCC, which is considered as one of the main sources of the PDCC, the Palestinian legislature must observe the necessary requirements in legislating a legal article imposing this obligation such as, the scope of this obligation in terms of subject matter, individuals, time, proving of this obligation and the penalty for its violation. Moreover, the Palestinian legislature must avoid the errors and inconsistencies which, in one way or another, diminish the efficiency of this legal means in ensuring contractual equilibrium between the contracting parties in the early phase of the contractual process.

In view of this, and in conjunction with the function of the obligation to maintain the confidentiality of information in the negotiation phase, the Palestinian legislature must intervene urgently by enacting a legal article which obligates the negotiating parties to maintain the disclosed confidential information. This should be done so as to let this obligation turn into a general legal obligation and a presumed obligation by the force of law. This has become an unavoidable reality that should be dealt with to contribute to the stability of civil 
and commercial transactions. To this end, it does not make sense to require a party to be legally obliged to provide important and influential information to the other party in order to contract freely and in an enlightened manner, without requiring the latter to maintain the confidentiality of information between the parties.

\section{REFERENCES}

Abdel Aal, H. M. (1998). The conventional organization of contractual negotiations. Cairo, Egypt: Dar Alnahdah Alearabiah.

Abdellah, K. R. (2000). Negotiate the contract. Cairo, Egypt: Dar Alnahdah Alearabiah.

Abdellah, Z. A. (2009). The legal protection of trade secrets in technology transfer contracts. Cairo, Egypt: Dar Alnahdah Alearabiah.

Abdul Ghani, M. (1998). Legal frame for the transfer of technology in public international law. Cairo, Egypt: Dar Alnahdah Alearabiah.

Abdul Rahman, A. F. (2010). Technology transfer contract in the new commerce code. Cairo, Egypt: Dar Alnahdah Alearabiah.

Abu El-Nemer, E. (2002). Negotiations of international trade contracts. Alharam, Egypt: Dar Abu El-Magd.

Ahmed, J. K. (2003). Obligation to inform in pre-contracting. Cairo, Egypt: Dar Alnahdah Alearabiah.

Al Mulla, A. (2017). The principle of good faith in contracts: Qatari law perspective. Asian Business Lawyer, 19, 115-134.

Al-Mahdi, M. N. (2009). The professional contracting party, its concept, obligations and liability, a comparative study. Cairo, Egypt: Dar Alnahdah Alearabiah.

Al-Mawla, K. N. (2003). The legal effects of technology transfer contracts. Amman, Jordan: Dar Wael for Publishing \& Distribution.

Al-Saadoon, O. (2010). Federal Iraqi law applicable to construction contracts. Arab Law Quarterly, 24(1), 105-118.

Aldsouki, I. M. (1995). Legal aspects of negotiations management and conclusion of contract. Riyadh, Saudi Arabia: General Administration of Research. 
Ali, H. W. (2010). Good faith in international sales, An analytical comparative study in light of international conventions and comparative legislation. Cairo, Egypt: Dar Alnahdah Alearabiah.

Alkalioubi, S. (2007). Al-Wasit in explaining the Egyptian commerce code, commitments, commercial contracts and operations of Banks. Cairo, Egypt: Dar Alnahdah Alearabiah.

Alkhamees, A. (2011). International transfer technology agreements: New age of negotiation. Asian Business Lawyer, 8, 143-156. Alsagher, A. H. (2005). Protect undisclosed information and the challenges facing pharmaceutical industries in developing countries. Alexandria, Egypt: Dar Al-Fikr Aljamiei.

Angheni, S. (2017). General Considerations on the contract as the main source of legal liability between traders. Law Annals from Titu Maiorescu University, 2017, 9-16.

Aryan, S., \& Mirabbasi, B. (2016). The good faith principle and its consequences in pre-contractual period: Comparative study on English and French law. Journal of Politics and Law, 9(2), 232-245.

Asfar-Cazenave, C. (2015). The new French contract law. Revue Juridique Themis, 49(3), 717-756.

Ashour, J. M. (2010). Technology investment contract. Beirut, Lebanon: Al-Halabi Legal Publications. 329-330.

Bambauer, D. E. (2016). Secrecy is dead long live trade secrets. Denver Law Review, 93(4), 833-854.

Cardenas, J. (2013). Deal jumping in cross-border merger acquisition negotiations: Comparative analysis of pre-contractual liability under French, German, United Kingdom and United States law. New York University Journal of Law and Business, 9(3), 941-976.

Coale, D. S. (2016). Commercial Litigation: 2014-2015. Texas Tech Law Review, 48(3), 587-618.

Davis, R. M. (2010). Trimming the Judicial Oak: Rule 10b5-2(b)(1), confidentiality agreements, and the proper scope of insider trading liability. Vanderbilt Law Review, 63(5), 1469-1506.

Dobrila, M. M. (2015). Unification of criteria for the assessment of good faith in negotiating contracts: From national to international through the intercession of the European Experience. AGORA International Journal of Juridical Sciences, 2015(2), 1-10. 
Doris, M. (2014). Promising options, dead ends and the reform of Australian contract Law. Legal Studies, 34(1), 24-46.

Finkin, M. W. (2017). Chapter 7: Privacy and Autonomy. Employee Rights and Employment Policy Journal, 21(2), 589-622.

Fischinger, P. S. (2010). Mobbing: The German law of bullying. Comparative Labor Law Policy Journal, 32(1), 153-184.

Foley, T. W. (2010). Keeping company's confidences secret: Trade secret enforcement under Iowa's Uniform Trade Secrets Act. Drake Law Review, 59(1), 1-40.

Frankel, M. J. (2012). Secret Sabermetrics: Trade secret protection in the baseball analytics field. Albany Government Law Review 5(1), 240-285.

Geier, A. (2014). Legal representation of clients with diminished legal capacity in Germany. Journal of International Aging Law Policy, 7, 1-24.

Gratzinger, P. E. (2015). After O2 micro: The court's evolving duty to map worlds to things. Santa Clara High Technology Law Journal, 32(2), 141-170.

Horton, W. G., \& Mathai, S. (2005). Confidentiality in Canadian civil litigation. Advocates' Quarterly, 29(4), 381-416.

Hwang, C. (2018). Deal momentum. UCLA Law Review, 65(2), $376-425$.

Ibrahim, M. A. (2006). Good faith in contracts. Beirut, Lebanon: Zain Legal Publications.

Jalloul, S. S. (2009). Practical Knowledge, study in concept, contracts and methods of protection. Beirut, Lebanon: AlHalabi Legal Publications.

Jamal, M. (2002). The willingness of contracting. Beirut, Lebanon: Al-Halabi Legal Publications.

Krishnan, L. (2013). Conceptualising a fiduciary Duty on auditors. UUM Journal of Legal Studies, 4, 57-77.

Law of Privileges of Inventions No. 22 of 1953. Retrieved from http://muqtafi.birzeit.edu/Legislation/GetLegFT. aspx?LegPath $=1953 \&$ MID $=1438$ visited on $20 / 11 / 2018$.

Law of Trademarks No. 33 of 1952. Retrieved from http://muqtafi.birzeit.edu/Legislation/GetLegFT. aspx?LegPath=1952\&MID=12149 visited on 20/11/2018.

Le Goff, P. (2007). Global law: Legal phenomenon emerging from the process of globalization. Indiana Journal of Global Legal Studies, 14(1), 119-146. 
Légifrance, le service public de la diffusion du droit, French Court of Cassation, social room, public sitting of Tuesday 8 December 2009, no of appeal: 08-17191. Retrieved from https://www. legifrance.gouv.fr/affichJuriJudi.do?oldAction=rechExpJuriJ udi\&idTexte $=$ JURITEXT000021472121\& fastReqId $=18112$ $21752 \&$ fastPos $=1$ visited on $24 / 11 / 2018$.

Légifrance, le service public de la diffusion du droit, French Court of Cassation, commercial room, public sitting of Tuesday, 26 May 2009, no of appeal: 08-16240. Retrieved from https:// www.legifrance.gouv.fr/affichJuriJudi.do?oldAction=rechEx pJuriJudi\&idTexte $=$ JURITEXT000020684744\&fastReqId= $639725987 \&$ fastPos $=72$ visited on 24/11/2018.

Légifrance, le service public de la diffusion du droit, French Court of Cassation, commercial room, public sitting of Tuesday 11 September 2012, no of appeal: 11-21322. Retrieved from https://www.legifrance.gouv.fr/affichJuriJudi.do?oldAction= rechExpJuriJudi\&idTexte $=$ JURITEXT000026375854\&fast ReqId $=1747833485 \&$ fastPos $=2$ visited on $24 / 11 / 2018$.

Légifrance, le service public de la diffusion du droit, French Court of Cassation, commercial room, public sitting of Tuesday 17 March 2015, no of appeal: 13-15862. Retrieved from https:// www.legifrance.gouv.fr/affichJuriJudi.do?oldAction $=$ rechEx pJuriJudi\&idTexte $=$ JURITEXT000030386043\& fastReqId $=$ $734898701 \&$ fastPos $=1$ visited on $24 / 11 / 2018$.

Légifrance, le service public de la diffusion du droit, French Court of Cassation, commercial room, public sitting of Tuesday 15 December 2015, no of appeal: 14-11500. Retrieved from https://www.legifrance.gouv.fr/affichJuriJudi.do?oldAction= rechExpJuriJudi\&idTexte $=$ JURITEXT000031652185\& fast ReqId $=76030935 \&$ fastPos $=1$ visited on $24 / 11 / 2018$.

Légifrance, le service public de la diffusion du droit, French Court of Cassation, civil room 1, public sitting of Monday 12 April 1976, no of appeal: 74-11730. Retrieved from https://www. legifrance.gouv.fr/affichJuriJudi.do?oldAction=rechExpJuriJ udi\&idTexte $=$ JURITEXT000006996257\& fastReqId $=15013$ $58316 \&$ fastPos $=63$ visited on 24/11/2018.

Légifrance, le service public de la diffusion du droit, French Court of Cassation, commercial room, public sitting of Wednesday 18 October 2017, no of appeal: 16-15891 16-15903. Retrieved 
from https://www.legifrance.gouv.fr/affichJuriJudi.do?oldA ction $=$ rechExpJuriJudi\&idTexte $=$ JURITEXT000035850159 $\&$ fastReqId $=1131035221 \&$ fastPos $=2$ 26/11/2018.

Légifrance, le service public de la diffusion du droit, French Court of Cassation, civil room 1, public sitting of Wednesday 1 June 2016, no of appeal: 15-13221. Retrieved from https://www. legifrance.gouv.fr/affichJuriJudi.do?oldAction=rechExpJuriJ udi\&idTexte $=$ JURITEXT000032635842\& fastReqId $=28955$ $9670 \&$ fastPos $=18$ visited on $27 / 11 / 2018$.

Légifrance, le service public de la diffusion du droit, French Court of Cassation, civil room 1, public sitting of Wednesday 1 June 2016, no of appeal: 15-16486. Retrieved from https://www. legifrance.gouv.fr/affichJuriJudi.do?oldAction=rechExpJuriJ udi\&idTexte $=$ JURITEXT000032637090\& fastReqId $=13214$ $11029 \&$ fastPos $=6$ visited on $27 / 11 / 2018$.

Légifrance, le service public de la diffusion du droit, French Court of Cassation, commercial room, public sitting of Wednesday 28 March 2018, no of appeal: 16-20018. Retrieved from https://www.legifrance.gouv.fr/affichJuriJudi.do?oldAction= rechExpJuriJudi\&idTexte $=$ JURITEXT000036780076\& fast ReqId=1097017314\&fastPos $=1$ 29/11/2018.

Légifrance, le service public de la diffusion du droit, French Court of Cassation, commercial room, public sitting of Wednesday 18 October 2017, no of appeal: 16-15900. Retrieved from https://www.legifrance.gouv.fr/affichJuriJudi.do?oldAction= rechExpJuriJudi\&idTexte $=$ JURITEXT000035850176\& fast ReqId $=1003148514 \&$ fastPos $=2$ visited on 29/11/2018.

Légifrance, le service public de la diffusion du droit, French Court of Cassation, civil room 3, public sitting of Thursday 27 April 2017, no of appeal: 16-11689. Retrieved from https://www. legifrance.gouv.fr/affichJuriJudi.do?oldAction=rechExpJuriJ udi\&idTexte $=$ JURITEXT000034554626\& fastReqId $=16856$ $07540 \&$ fastPos $=5$ visited on $29 / 11 / 2018$.

Légifrance, le service public de la diffusion du droit, French Court of Cassation, commercial room, public sitting of Wednesday 14 November 2018, no of appeal: 16-22845. Retrieved from https://www.legifrance.gouv.fr/affichJuriJudi.do?oldAction= rechExpJuriJudi\&idTexte $=$ JURITEXT000037644590\& fast ReqId=907237637\&fastPos $=1$ visited on 29/11/2018. 
Légifrance, le service public de la diffusion du droit, Lyon Court of Appeal, public sitting of Thursday 20 January 2005, no of appeal 03/03119. Retrieved from https://www.legifrance. gouv.fr/affichJuriJudi.do?oldAction=rechExpJuriJudi\&idTe $\mathrm{xte}=$ JURITEXT000006944634\&fastReqId $=628913753 \&$ fas tPos $=2$ 29/11/2018.

Légifrance, le service public de la diffusion du droit, Lyon Court of Appeal, civil room 3, public sitting of Thursday 9 March 2006, no of appeal 04/04968. Retrieved from https://www. legifrance.gouv.fr/affichJuriJudi.do?oldAction=rechExpJuriJ udi\&idTexte $=$ JURITEXT000006949155\& fastReqId $=56088$ $1028 \&$ fastPos $=1$ visited on 29/11/2018.

Li, X. (2017). The legal status of pre-contractual liability: Contrasting responses from German and English law. National Taiwan University Law Review, 12(1), 127-175.

Loncle, J., \& Trochon, J. (1997). La phase de pourparlers dans les contrats Internationaux. International Business Law Journal, 1997(1), 3-38.

Lutf, H. M. (1995). Civil responsibility in the negotiation phase, a study in Egyptian and French law. Cairo, Egypt: Al-Nacre Al-Dahabieh.

Mace, A. C. (2009). TRIPS, E-Bay, and denials of injunctive relief: Is Article 31 compliance everything. Columbia Science and Technology Law Review, 10, 232-266.

Malami, S., \& Yusoff, Z. M. (2017). Legal regime for the protection of banking consumers in Nigeria: an overview. UUM Journal of Legal Studies, 8, 87-112.

Mandelbaum, J., Swartz, S., \& Hauert, J. (2016). Periodic review in natural resource contracts. Journal of Sustainable Development Law and Policy, 7(1), 116-136.

Mansour, H. M. (2009). International contracts. Alexandria, Egypt: Dar Al-Jamieat Al-Jadidah.

Marsden, G. J., \& Siedel, G. J. (2017). The duty to negotiate in good faith: Are BATNA strategies legal. Berkeley Business Law Journal, 14, 127-156.

Melhem, H. S. (2005). Negotiating contracts through the internet. Nahrain University Journal, 13(8), 73-115.

Mohammedine, W. J. (2004). The legal frame of technology transfer. Alexandria, Egypt: Dar Al-Jamieat Al-Jadidah. 
Nahan, N. (2015). Duty of confidence revisited: The protection of confidential information. University of Western Australia Law Review, 39(2), 270-293.

Nashkova, S. (2016). Overview of contractual obligations of the know-how licensor under the Macedonian law of obligations. Collection of Papers, Faculty of Law, Nis 72, 363-382.

New French Civil Code, which was created by Decree N 131-2016 of 10 February 2016.

Olsson Jr, Harry R. (1958). Dreams for sale: Some observations on the law of idea submissions and problems arising therefrom. Law and Contemporary Problems, 23(1), 34-61.

ORGALIME GUIDES, orgalime, publications, model forms. Retrieved from https://publications.orgalime.org/ visited on 23/11/201Palestinian Civil Code Draft.

Palestinian Law No. (21) of 2005 Concerning Consumer Protection. Reuben, R. C. (2018). Rethinking the law of legal negotiation: Confidentiality under Federal rule of Evidence 408 and related State Laws. Boston College Law Review, 59(2), 523-590.

Roach, G. P. (2007). How restitution and unjust enrichment can improve your corporate claim. Review of Litigation, 26(2), 265-400.

Saleh, A. A. (2011). Negotiations in international commercial contracts. Algeria, Algeria: Dar Houma.

Santoso, E. (2012). Consumer protection for online banking scams via e-mail in Malaysia. UUM Journal of Legal Studies, 3, $1-22$.

Sarii-Aldiyn, S. H. (2001). Technology Transfer Contract in the New Commerce Code. Cairo, Egypt: Dar Alnahdah Alearabiah.

Shabalala, D. (2017). Access to trade secret environmental information: Are trips and trips-plus obligations hidden timeline. Columbia Journal of Transnational Law, 55(3), 648-717.

Sharfuddin, A. (2008). Principles of legal drafting of contracts. Cairo, Egypt: Dar Alnahdah Alearabiah. 74.

Suleiman, A. S. (2008). Good faith in concluding contracts. Amman, Jordan: Dar Dijla.

Telep, J. M., \& Cohen, J. Y. (2011). FinCen publishes final rule and interpretive guidance clarifying the scope of Sar's Confidentiality Provisions. Banking Law Journal, 128(3), 227-231. 
Tessema, Y. (2016). The legal framework for the transfer of technology in Ethiopia. Journal of Law, Policy and Globalization, 55, 148-181.

Thomas, D. (2012). Standard form construction and engineering contracts: Current and recent developments. Construction Law International, 7(2), 33-34.

TRIPS Convention for Trade-Related Aspects of Intellectual Property Rights.

Valentino, D. (2016). Software assistance and maintenance contracts. European Business Law Review, 27(4), 535-554.

van Houtte, H. (2014). Contract negotiations and the Unidroit principles. Uniform Law Review, 19(4), 550-560.

Waldzus, D. (2014). Germany pre-contractual disclosure requirements and relevant case law. International Journal of Franchising Law, 12(5), 3-10.

Wei, G. (2005). Breach of confidence, downstream losses, gains and remedies. Singapore Journal of Legal Studies, 2005(1), 20-63.

White, A. M. (2017). Foreclosure diversion and mediation in the states. Georgia State University Law Review, 33(2), 411-454.

Woss, H. (2008). The ICC model Turnkey contract for major projects. Construction Law International, 3(2), 6-11. 